\title{
NTO-S-0035
}

\section{WELDING STANDARDS}

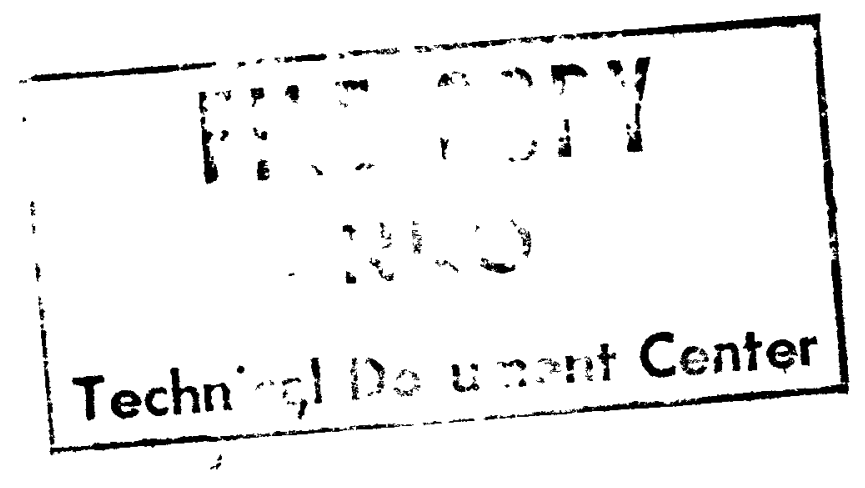

, FINAL ISSUE

\section{OCTOBER 18, 1968}

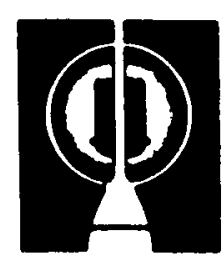

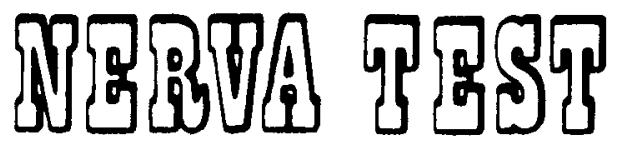

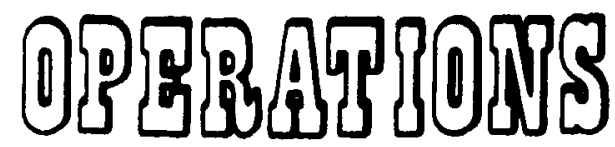

Jackass Flats, Novada 


\section{DISCLAIMER}

This report was prepared as an account of work sponsored by an agency of the United States Government. Neither the United States Government nor any agency Thereof, nor any of their employees, makes any warranty, express or implied, or assumes any legal liability or responsibility for the accuracy, completeness, or usefulness of any information, apparatus, product, or process disclosed, or represents that its use would not infringe privately owned rights. Reference herein to any specific commercial product, process, or service by trade name, trademark, manufacturer, or otherwise does not necessarily constitute or imply its endorsement, recommendation, or favoring by the United States Government or any agency thereof. The views and opinions of authors expressed herein do not necessarily state or reflect those of the United States Government or any agency thereof. 


\section{DISCLAIMER}

Portions of this document may be illegible in electronic image products. Images are produced from the best available original document. 
peviewed by: $\frac{\text { a deforenzo }}{\text { C. A. DeLorenzo, Manager }}$

This document supersedes:

S-0001 through S-0012
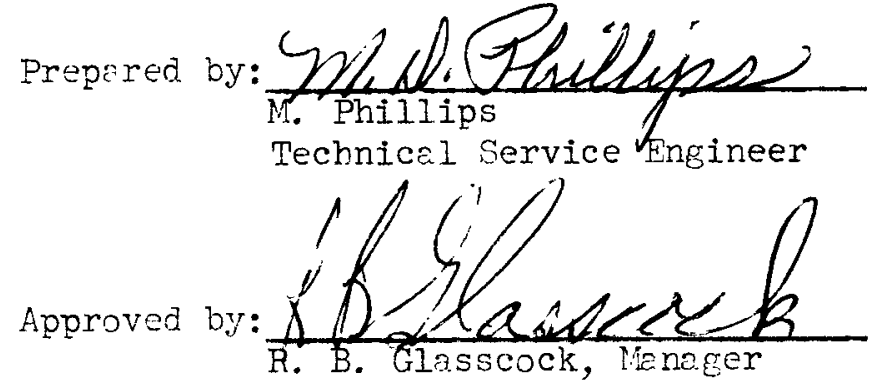

NTO Product Assurance

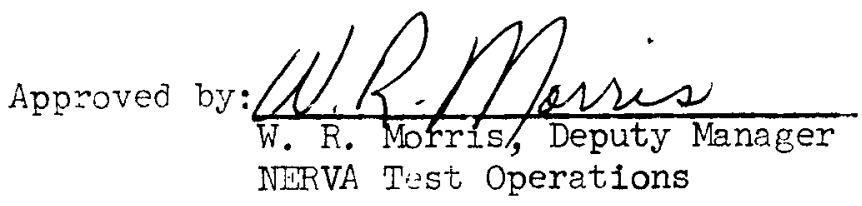

Approved by: w.X wayne

W. D. Wayne, Manflger NERVA Test Operations

FINAL ISSUE

October 17, 1968 
I"IO-S - $\cos 35$

TABLE OF CONTENTS

(Continued)

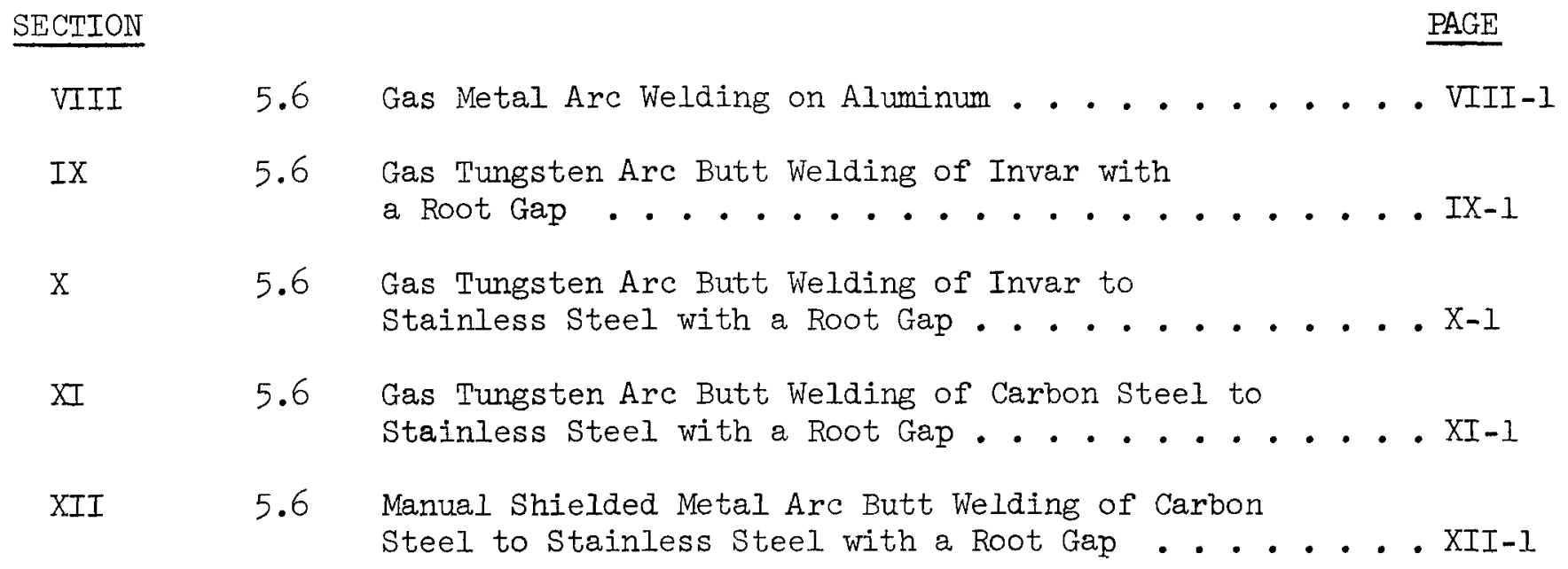

FIGURES

1

EDGE PREPARATION

2 EDGE PREPARATION

3 LOCATION OF ' $Y$ ' RING

4 MEAN AMPERAGE VALUES

5 MEAN AMPERAGE VALUES

6 TEST WELD FOR EQUIPMENT CHECK 
1.0 PURPOSE

The purpose of this standard is to establish the use of standard welding techniques through procedure implement-tion, and specification and operator qualification.

\subsection{QUALIFICATION GUIDE}

\subsection{WEIDER QUALIFICATION}

2.1.1 Welders performing welding on the test article and directly associated hardware using this procedure shall be qualified in accordance with MIL-T-5021 or NTO-QCS-1ll.

2.1.2 Welders performing welding on all support equipment or hardware using this procedure shall be qualified in accordance with MIL-STD-248.

2.1.3 A weld procedure must be satisfactorily qualified in accordance with the required certification test and submitted for approval prior to the performance of any production welding.

2.2 QUALIFICATION OF NONDESTRUCTIVE TESTING (NDT) PERSONNEL

2.2.1 Personnel performing nondestructive testing shall be qualified in accordance tith NTO-QRI-13.1.

\subsection{REQUIREMENTS}

3.1 NONDESTRUCTIVE TESTING (NDT)

3.1.1 All liquid penetrant examinations, if specified on the drawing or applicable NTO specification, shall be performed in accordance with NTO-QCS-107. 
3.1.2 All magnetic particle examinations, if specified on the drawing or applicable NTO specification, shall be performed in accordance with NTO-QCS-108.

3.1.3 All radiography, if specified on the drawing or applicable NTO specification, shall be performed in accordance with NTO-QCS-105A.

\subsection{CLEANLINESS IEVEL}

3.2.1 Welding operations conducted as the final weld on a piping system which has previously been cleaned to a precision cleanliness level shall not contaminate the subject system. The welding operation cleanliness shall conform to NTO-QCS-II2 with the level established for the system.

3.2.2 Where a line which has been certified clean is affected, appropriate plugging methods are to be used to maintain system cleanliness, i.e., plastic bags or expandable plugs. Prior to and after removing the plug, the entire weld area and the affected area shall be wiped clean with a lint-free cloth saturated with reagent-grade Methyl Ethyl Keton (MEK) for the removal of grease, finger. prints, or other contaminants.

\subsection{IDENTIFICATION}

3.3.1 Each weld shall be identified with a symbol orienting its location and the welding operators symbol.

3.3.2 Symbols shall be vibratol etched adjacent to the weld on the base metal. Penetration of the etch shall be 
done in a workmanshiplike manner, limited to producing a readable image and shall not cause damage to the welded assembly.

4.0 APPLICABLE DOCUNENTS

The following specifications and publications of the issues indicated by date form a part of this specification to the extent specified herein. Where no date is indicated, the applicable issue shall be the latest in effect.

Military

$\begin{array}{ll}\text { MII-STD-248 } & \text { Qualification Tests for Welders } \\ \text { MII-T-5021 } & \begin{array}{l}\text { Tests: Aircraft and Missile Welding } \\ \text { Operators Qualification }\end{array} \\ \text { MIL-STD-410 } & \begin{array}{l}\text { Qualification of Inspection Personnell, } \\ \text { Magnetic Particle and Penetrant }\end{array} \\ \text { MII-R-5031 } & \text { Rods and Wire, Welding, Corrosion and Heat } \\ & \text { Resistant Alloys } \\ \text { MII-R-5632 } & \text { Rods; Steel Welding } \\ \text { MIL-E-22200-2 } & \text { Electrodes, Welding, Covered (Austenitic } \\ & \text { Chromium Nickel Steel) for Corrossive and } \\ & \text { High Temperature Service } \\ \text { MII-E-22200/1 } & \text { Electrodes, Welding, Mineral Covered, Iron } \\ & \text { Powder, Low Hydrogen Medium and High Tensile } \\ & \text { Steel, AS welding or Stress - Relieved } \\ & \text { Application. } \\ & \text { Electrodes, Welding, Bare, Aluminum Alloys }\end{array}$

Other

$$
\begin{aligned}
& \text { NTO-QCS-112 } \\
& \text { NTO-QCS-107 } \\
& \text { NTO-QCS-108 }
\end{aligned}
$$

Levels of Cleanliness

Iiquid Penetrant Examination of Weldments Magnetic Particle Examination of Weldments 


$$
2 \operatorname{mn}-5-0035
$$

NTO-QCS-105A Radiography of Fusion Welds

NTO-QCS-III Missile Welding Operators Qualification

NTO-QRT-131 Certification of Non-Destructive Testing Personnel

ASME, Sec. VIII Unfired Pressure Vessel Code

\subsection{WEIDING PROCEDURE}

5.1 INERT GAS INTERIOR PURGE

5.1.1 The interior purge shall be acceptable for welding when

a volume of welding-grade Argon or Helium equal to ten

times the volume of the system has passed through the system at a flow rate not to exceed $60 \mathrm{CFH}$.

NOTE: In all Tacking, 10CFH Argon will be used as a backup.

5.1.2 Internal purge rates shall be reduced to $5-20 \mathrm{CFH}$ prior to welding. The exhaust vent from the pipe and cap shall be $3 / 16^{\prime \prime}$ tubing.

\subsection{WEID PREPARATION}

5.2.1 The edges or surfaces of the parts to be joined by welding shall be prepared by machining or grinding as shown in Figure 1. The weld area and one inch each side thereof shall be cleaned of all slag, burrs, oil, grease, and dirt to present a clean and substantially smooth surface for welding. Thoroughly clean all foreign material from inside of passages.

5.2.2 Remove all oxides from the weld area prior to laying a tack or bead. 
5.2.2.1 Steel - abrasive papers or a stainless steel wire brush are acceptable means for oxide removal.

5.2.2.2 Aluminum - The weld area shall be wire brushed, using a stainless steel brush and wiped with a clean, lint-free cloth saturated with chemically pure Acetone within one hour prior to the start of welding.

\section{$5.3 \quad$ TACK WEIDING}

5.3.1 Tack spacing will be determined by condition and size of the items being welded. In no case will tacks be over $2-1 / 2$ inches apart.

5.3.2 Tack in sequence per the following diagram:

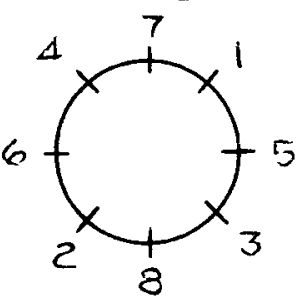

5.3.3 Tack welds shall be small, and proportionate to the pipe size to retain tack-up position, and made by the same process as the initial root bead, producing a quality weld. 5.3.3.1 Do not 'flame' or 'arc gouge' weld area.

5.3.3.2 Tack welds must be either removed or blended in a manner to prevent entrapment of defects or interruption of the weld pass. Blending of tack welds may be accomplished by using a rotary file or burr.

5.3.3.3 Cracked or improper tacks shall be removed. 
NTO-S-0035

5.3.3.4 Precautions must be taken at all times to protect the welding wire from dirt, grease, oil, moisture, or other forms of contamination.

5.4 WELDING

5.4.1 Establish a purge 5 to $20 \mathrm{CFH}$ or Argon before welding and maintain this purge until a minimum of $3 / 16$ inch or three layers of weld have been deposited. Purging may be then discontinued unless a level of cleanliness is required and must be maintained.

NOTE: NOT APPLICABLE TO MANUAL SHIEIDED ARC PROCESS.

5.4.2 Deposit all welding passes in the same sequence as the tacks. The number of weld increments will be determined by the pipe size. The length of the weld deposits (increments) should not exceed 3 inches for pipe over 6 inch diameter and 2 inches for pipe less than 6 inch diameter to eliminate distortion, and changes in physical properties of the base material.

5.4.3 Stagger the starts and ends of increments to avoid start and stop occurrences in the same area through the depth of the joint.

5.4.4 Whenever the material temperature is below $60^{\circ} \mathrm{F}$, preheat prior to welding. Steel and Invar $-60^{\circ} \mathrm{F}$.

$$
\text { Aluminum - } 120-150^{\circ} \mathrm{F} \text {. }
$$

5.4.5 Do not exceed interpass temperatures specified for each type of weld. Tempilsticks or equivalent measuring crayons may be used after each pass to check the temperature of the base metal. Apply the tempilstick to the base metal adjacent to the weld. 
5.4.6 Thoroughly clean oxides of each completed bead or layer with a stainless steel wire brush and wipe with a suitable solvent.

Steel and Invar - Reagent grade MEK

Aluminum - Chemically pure Acetone

5.4.7 Remove all extraneous weld material from the weld surface before laying down the next bead or layer.

5.4.7.1 The torch should be held such that the electrode is on a radius line at all times. 5.4.7.2 Intermediate arc stops are to be made by reversing the movement of the torch. Restart overlap for the root pass shall be $3 / 4$ " to I" in length.

5.4.8 Visually inspect and remove any cracks or blowholes that appear on the welding surface before restarting an arc and also at the completion of the weld.

5.4.9 Observe drawing or applicable specifications requiring Nondestructive testing of tacks, root passes or completed welds.

5.4.9.1 The root pass on all welds in piping 8 inches in diameter or larger whose thickness is schedule 160 or greater shall be radiographed if radiography is required for the completed weld. 
NTO-S-0035

5.5 SPECIFIC TYPE WELDS, METHODS OF

5.5.1 Stainless Steel/Gas Tungsten Arc with ' $Y$ ' Rings

Proceed per Section I

5.5.2 Stainless Steel/Gas Tungsten Arc with Root Gap

Proceed per Section II

5.5.3 Stainless Steel/Manual Shielded Metal Arc

Proceed per Section III

5.5.4 Carbon Steel/Gas Tungsten Arc with ' $Y$ ' Rings.

proceed per Section IV

5.5.5 Carbon Steel/Gas Tungsten Arc with Root Gap

Proceed per Section V

5.5.6 Carbon Steel/Manual Shielded Metal Arc with Root Gap

Proceed per Section VI

5.5.7 Aluminum/Gas Tungsten Arc

Proceed per Section VII

5.5.8 Aluminum/Gas Metal Arc

Proceed per Section VIII

5.5.9 Invar/Gas Tungsten Arc with Root Gap

Proceed per Section IX

5.5.10 Invar to Stainless/Gas Tungsten Arc with Root Gap.

Proceed per Section X

5.5.11 Carbon Steel to Austenitic Stainless Steel/Gas Tungsten Arc with Root Gap

Proceed per Section XI

5.5.12 Carbon Steel to Austenitic Stainless Steel/Manual

Shielded Metal Arc with Root Gap.

Proceed per section XII 
NPO-S-0035

$6.0 \quad \underline{R E P A I R}$

6.1 Remove weld defects per 6.1.1 or 6.1.2 as applicable. 6.1.1 Steel - Defects shall be removed by using a small rotary file or by grinding providing this operation does not include breaking completely through the weld into the inside of the pipe.

6.1.2 Aluminum - Defects shall be removed by filing or chipping without breaking through the weld into the pipe.

6.2 The reworked area shall be liquid dye penetrant inspected per NTO-QCS-107 to insure complete removal of the defect. If this inspection reveals the continued presence of the defect, step 6.1 shall be repeated.

6.3 Remove all dye penetrant and developer per 6.3.1 or 6.3.2 as applicable. 6.3.1 Steel and Invar - Wipe with clean, lint-free cloth saturated in reagent-grade $M E K$.

6.3.2 Aluminum - Wipe with clean, lint-free cloth saturated in chemically pure acetone.

6.4 Where complete removal of defects can be accomplished and still meet the requirements of step 6.1 , the second weld pass may be made directly over the reworked area.

6.5 Where complete removal of the defect cannot be accomplished without breaking through the inside surface of the weld, the defect will be recorded on an inspection report; and NTO and Source Engineering will be contacted for resolution of the problem. 


$$
-A-
$$

butt joints without backing rings for horizontal fixed and vertical fixed positions

$$
-B-
$$

butt joints with backing rings for horizontal rolled position only

$$
\text { - C- }
$$

butt joints with backing rings for vertical fixed position

$$
\text { -D - }
$$

butt joints with backing rings for horizontal fixed position
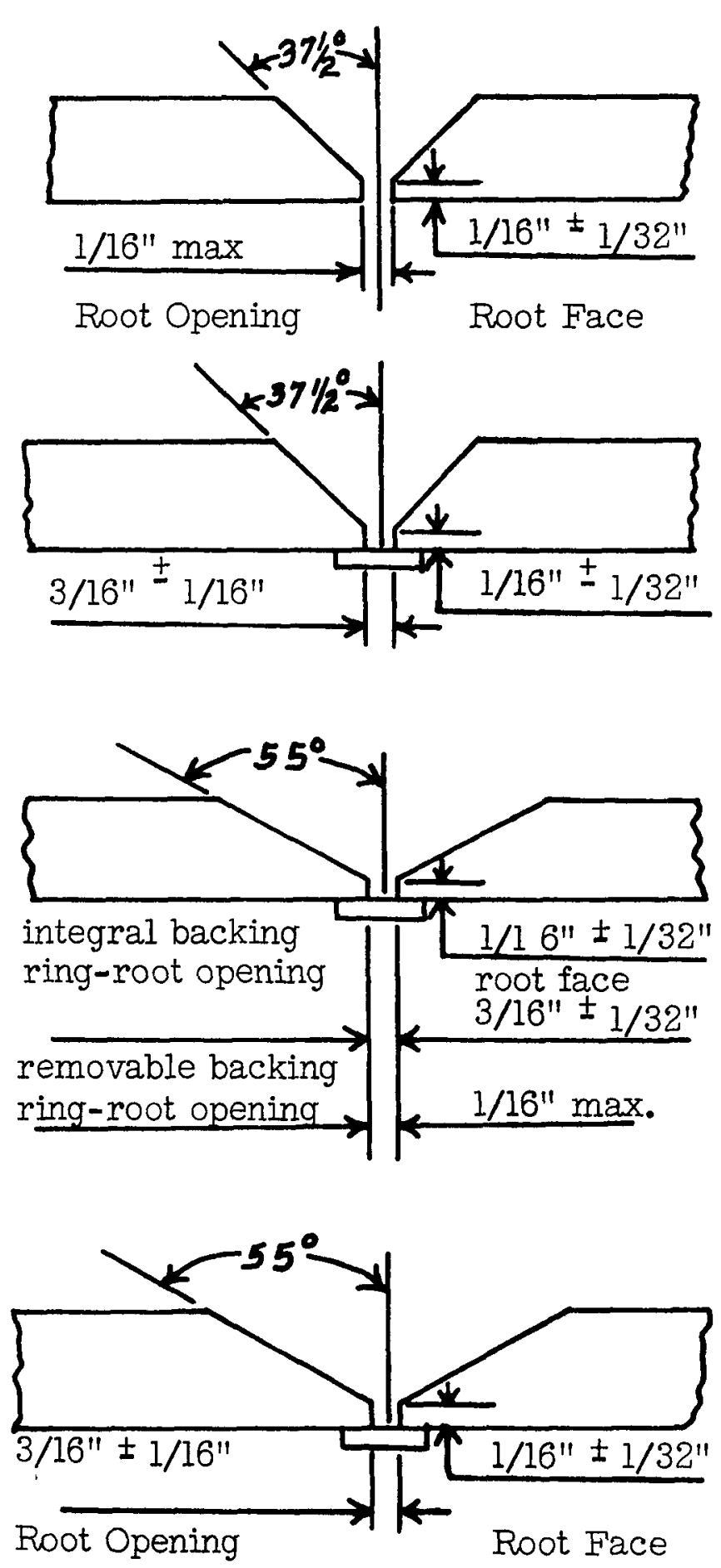

\section{FIGURE I Edge Preparation}




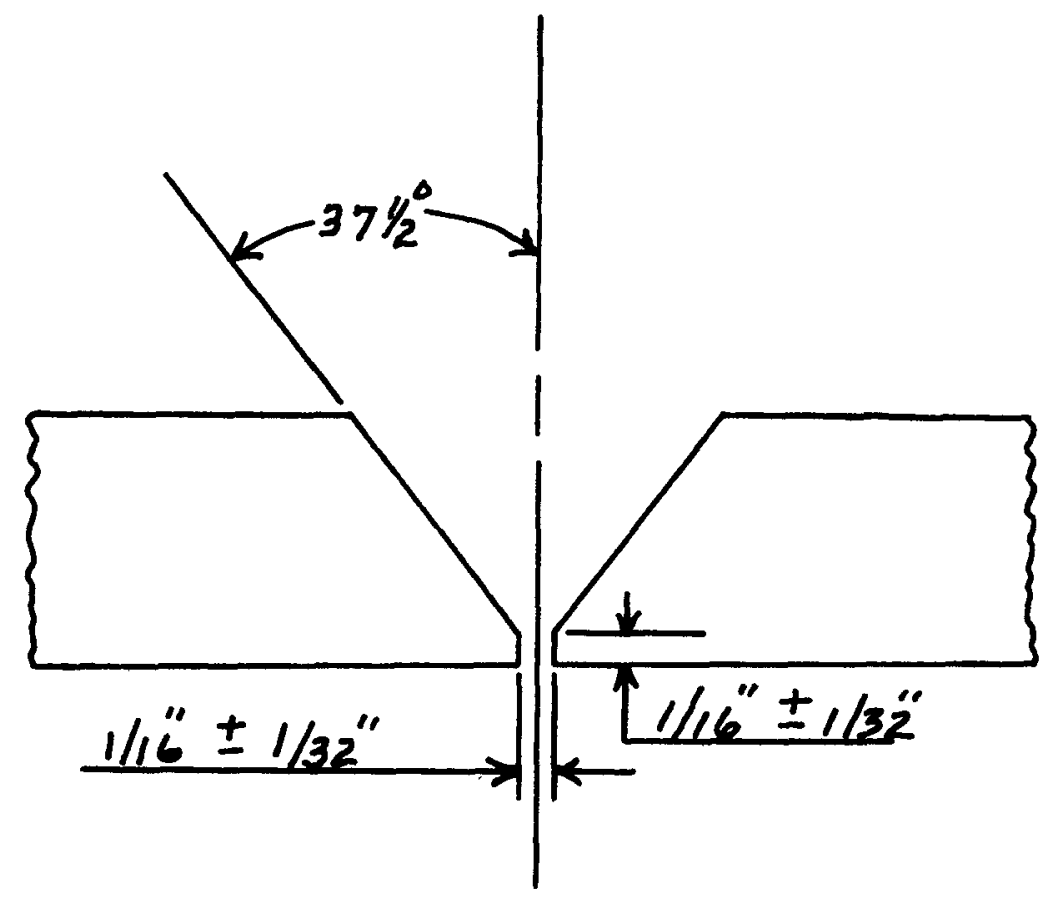

FIGURE2 Edge Preparation 


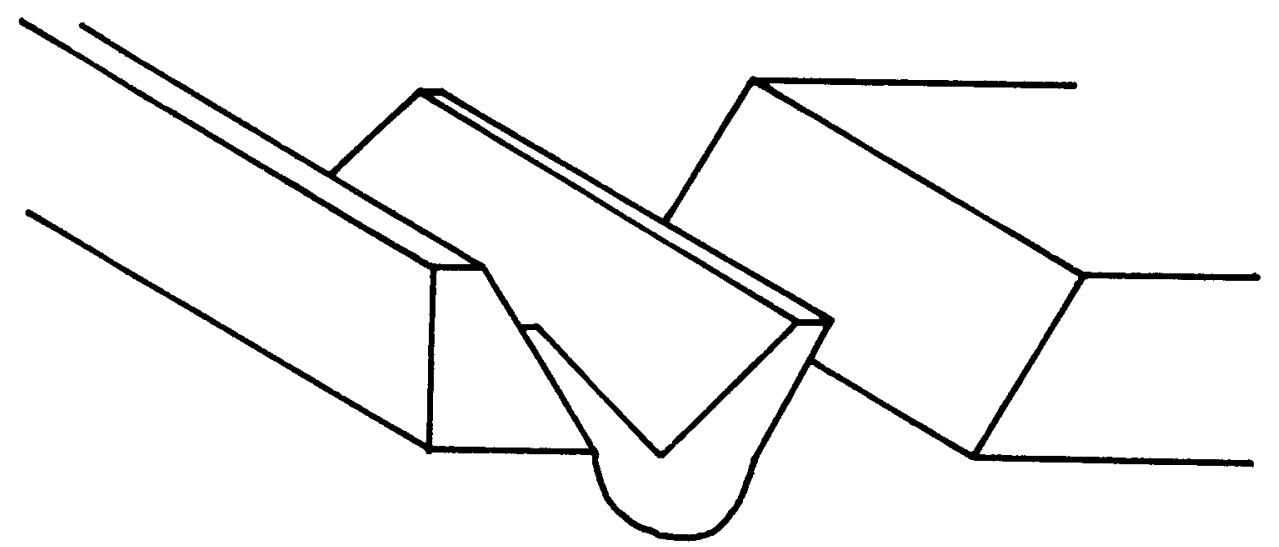

FIGURE 3 Location of "Y" Ring 
Material

Thickness

$1 / 8^{\prime \prime} \pm 1 / 16^{\prime \prime}$

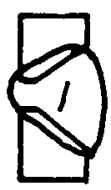

$1 / 4^{\prime \prime}+1 / 16^{\prime \prime}$

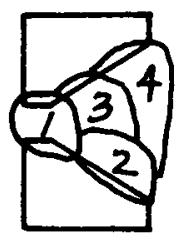

3-5 passes

120-180 amps

$1 / 8$ " electrode

$5 / 32$ "filler wire

\section{Ring}

1-2 passes

60 - 110 amps

1/8" electrode

$1 / 8$ " filler wire
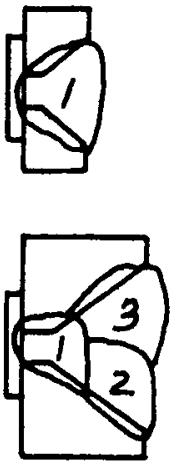

$5-7$ passes

180-220 amps

$5 / 32 "$ electrcde

$5 / 32^{\prime \prime}$ filler wire
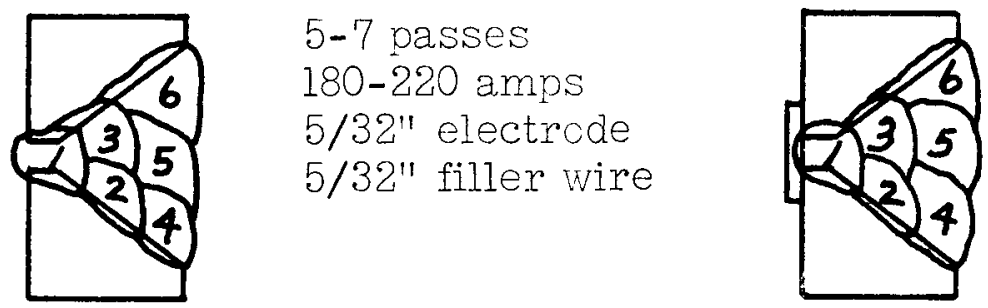

7-11 passes

220-240 amps

$3 / 16^{\prime \prime}$ electrode

$3 / 16^{\prime \prime}$ filler wire

7-11 passes

220-250 amps

$3 / 16^{\prime \prime}$ electrude

$3 / 16^{\prime \prime}$ filler wire
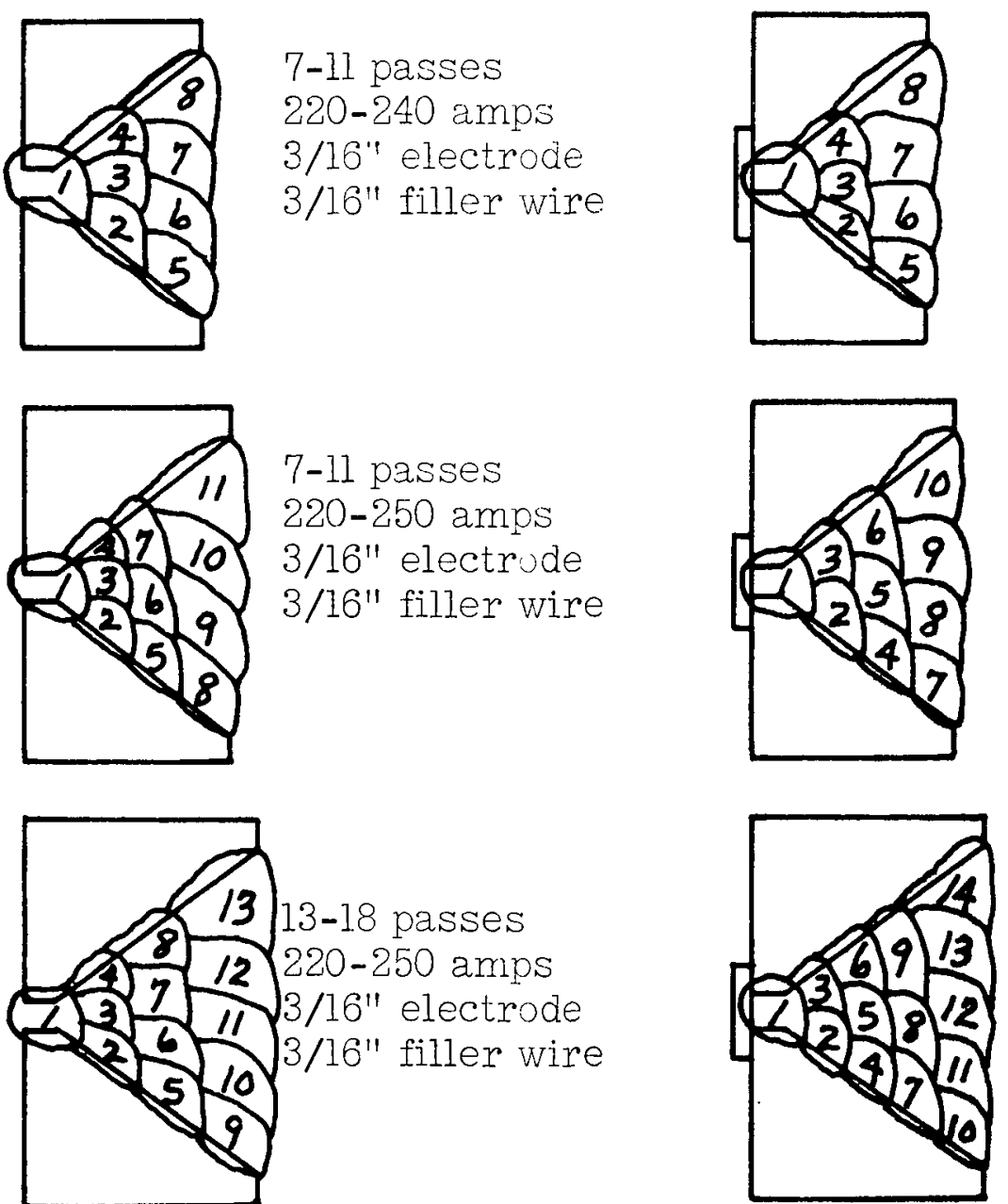

$3 / 4^{\prime \prime} \pm 1 / 16^{\prime \prime}$

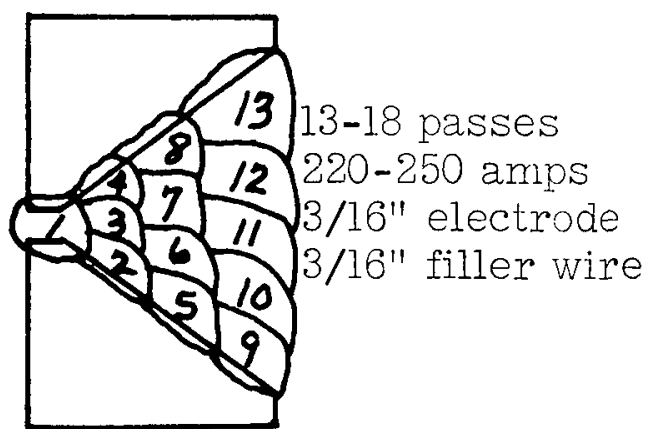

With Backing Ring

1-2 passes

70-120 amps

1/8" electrode

1/8" filler wire

3-5 passes

140-200 amps

$1 / 8^{\prime \prime}$ electrode

$5 / 32$ " filler wire

5-8 passes

23-270 amps

$5 / 32 "$ electrode

$5 / 32^{\prime \prime}$ filler wire
7-11 passes

230-280 amps

$3 / 16^{\prime \prime}$ electrode

$1 / 16^{\prime \prime}$ filler wire
7-11 passes

230-280 amps

$3 / 16^{\prime \prime}$ electrode

$3 / 16^{\prime \prime}$ filler wire

13-18 passes

230-280 amps

$3 / 16^{\prime \prime}$ electrode

$3 / 16^{\prime \prime}$ filler wire

FIGURE 4 Mean Amperage Values 
Material

Thickness

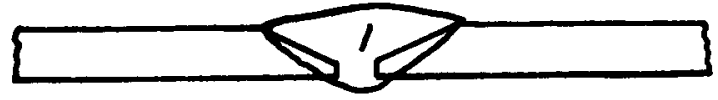

1/8" 1-2 passes

$\begin{array}{ll} \pm 1 / 16^{\prime \prime} & 60-100 \text { amps } \\ 1 / 8^{\prime \prime} \text { electrode }\end{array}$

$1 / 8^{\prime \prime}$ filler wize

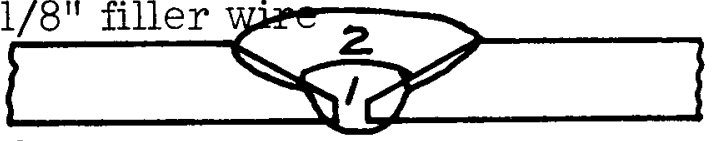

1/4" 2 passes

$\pm 1 / 16^{\prime \prime} \quad 100-150$ amps

$1 / 8$ " electrode

$1 / 8^{\prime \prime}$ filler wire

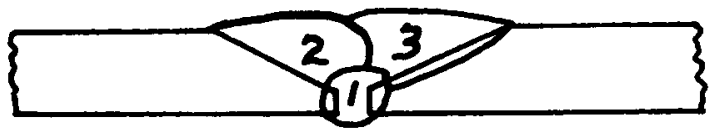

3/8" 2-3 passes

$\pm 1 / 16^{\prime \prime} \quad$ 150-190 amps

5/32" electrode

$5 / 32$ "filler wire

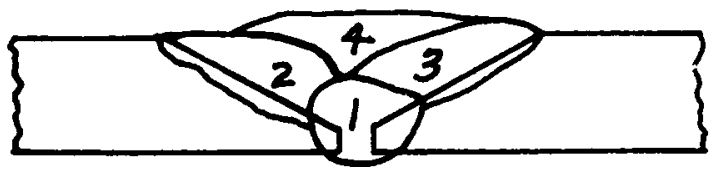

$1 / 2^{\prime \prime} \quad 3-5$ passes

$\pm 1 / 16^{\prime \prime} \quad 190-210$ amps

$3 / 16^{\prime \prime}$ electrode

$3 / 16^{\prime \prime}$ filler wire

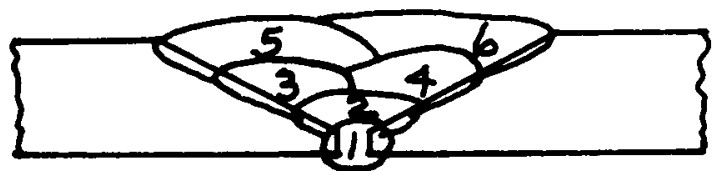

5/8" $\quad 5-7$ passes

$\pm 1 / 16^{\prime \prime} \quad 190-210$ amps

$3 / 16^{\prime \prime}$ electrode

$3 / 16$ " filler wire

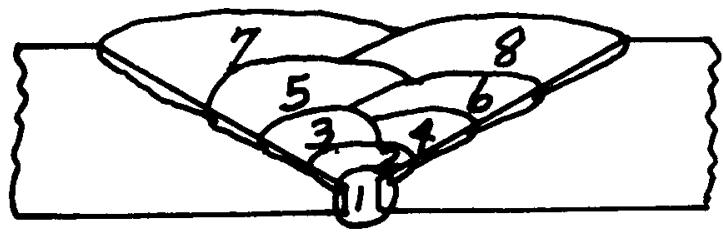
$3 / 4^{\prime \prime}$
7-10 passes
$3 / 16^{\prime \prime}$ electrode
$\pm 1 / 16^{\prime \prime}$
190-210 amps
$3 / 16^{\prime \prime}$ filler wire

With Backing Ring
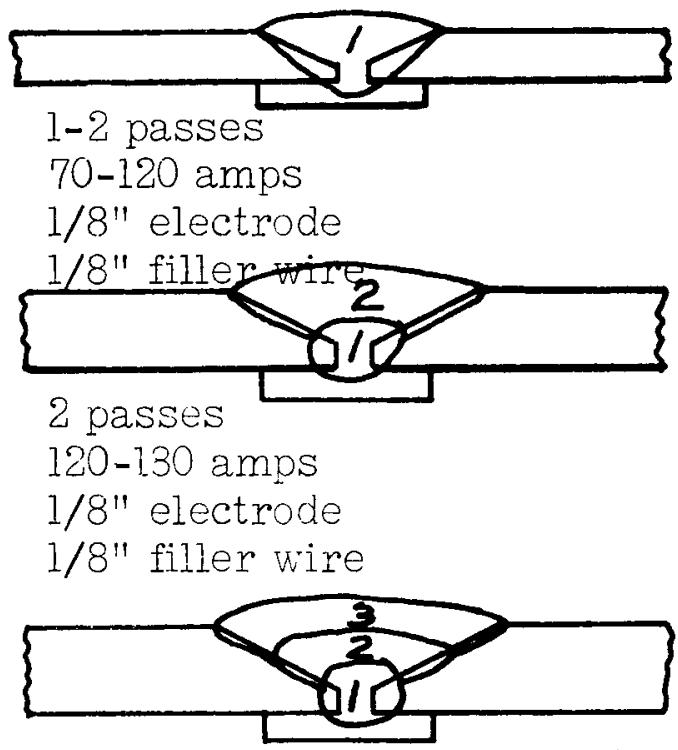

$2-3$ passes

180-250 amos

$5 / 22 "$ electrode

$5 / 32 "$ filler wire

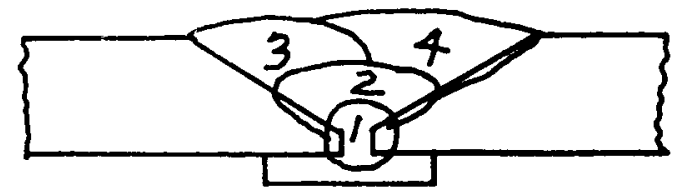

$3-5$ passes

200-270 amps

3/16" electrode

$3 / 56 "$ filler wire

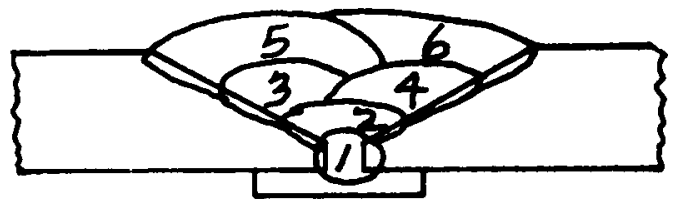

5-7 vasses

200-270 amps

3/16" electrode

s/15" filler wire

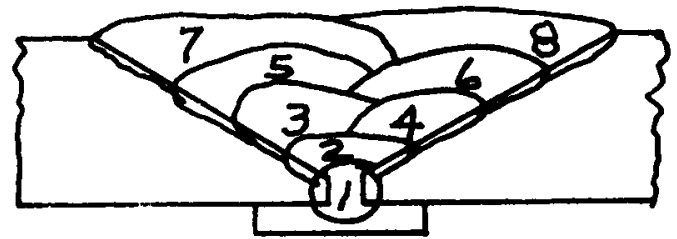

7-10 asises

3/16" electrode

$200-, 170$ amps

$3 / 16^{\prime \prime}$ filler wire

\section{FIGURE 5 Mean Amperage Values}



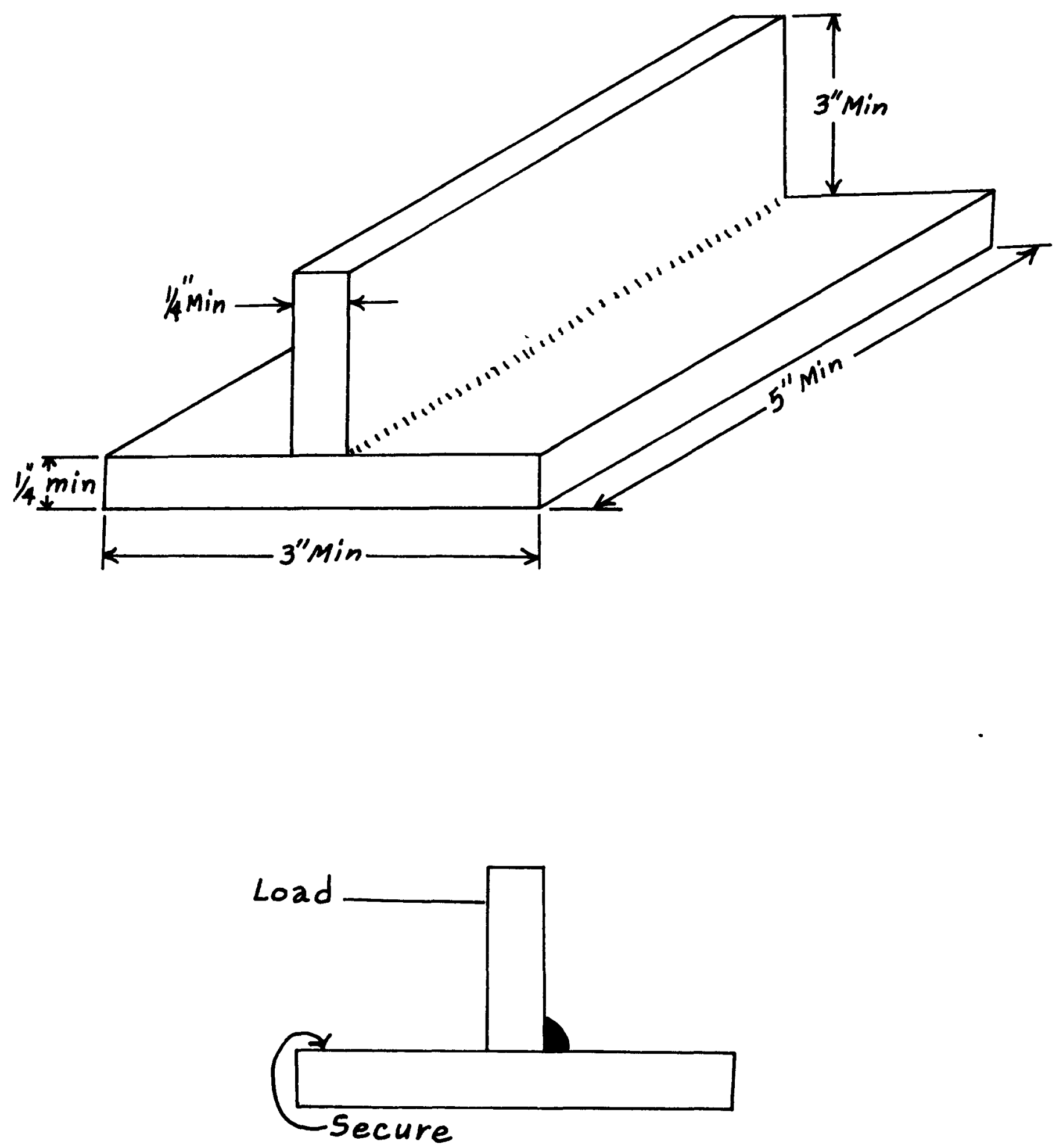

FIGURE 6 Test Weld For Equipment Check 
NTO-S-0035

\section{SECTION I}

5.6 Gas Tungsten Arc Butt Welding in conjunction with ' $Y$ ' Type consumable inserts for 300 Series Stainless Steel. 5.6.1 Paragraphs 1.0 through 5.5 are an integral part of this procedure.

5.6.2 The ' $Y$ ' Ring Insert shall be made of a material compatible with both the base material and the filler material. 5.6.2.1 The ' $Y$ ' Ring Insert shall be cleaned of all oxides by methods described in section 5.2 .2 , prior to tack welding.

5.7 TACK WELDING OF ' $Y$ ' RING INSERT

5.7.1 Tack welding of the ' $Y$ ' Ring Insert is not required if the insert is a pre-formed solid ring and the joint can be clamped in position.

5.7.2 Where tack welds are used, the fusion of the insert arm to the bevel is sufficient. A tack weld spacing of $2-4$ inches is adequate. All tack welds shall be made on the outside of the part.

5.7.3 Locate the ' $Y$ ' ring on one side of joint as shown in Figure 3. Then tack weld as per 5.7.2. Rings over $1 / 2^{\text {" }}$ in diameter are rolled with an overlap. Tack to first assembly section to within a few inches of overlap then secure the overlap with a vice-grip pliers and saw completely through the side-by-side insert sections. This 
will leave a gap the width of the saw blade which is to be bridged with weld rod after the interior purge is complete and prior to starting the weld. Iocate the second half of the assembly in its proper position, and tack weld using a slight offset sequence from the first set of tacks.

5.8 ALIGNMENT

5.8.1 The outward inclined arms of the " $Y$ " Ring Insert creates a double-cup effect with the assembly becoming self-aligning.

5.8.2 In cases where there is local misalignment between the two pipes which are to be welded, the insert arm may be pushed into position.

5.8.3 Where large misalignment gaps exist, it is necessary that filler metal be added simultaneously with reduction of the insert. The filler rod is held in contact with the inset vee of the "Y" Ring Insert and allowed to enter the weld puddle without rod movement as the arc advances.

\subsection{ROOT WEIDS}

5.9.1 Interpass temperature must not exceed $350^{\circ} \mathrm{F}$.

5.9.2 Prior to starting the root pass, a $1 / 2$ " Iong weld should be started $180^{\circ}$ from the point the weld bead is to be started. If the weld is not to be started immediately, a second $1 / 2 "$ long weld should be made at the starting point ( $180^{\circ}$ from the first $1 / 2^{\prime \prime}$ long weld).

5.9.3 Vertical welds (pipe in the horizontal plane) shall be started at the bottom of the pipe and proceed towards the top. 
NTO-S-0035

Section I

5.9.4 Advancement of the torch is determined by breakdown of the Vee formed by inclined arms of the insert. As the arms are melted and drawn into the crater, there is a "wetting action" up the beveled sides. The molten weld surface becomes slightly concave as the root-pass fusion is established.

5.9.5 Torch movement should be in a forward direction of travel. Side movement or weaving shall not exceed the width of the "Y" Ring Insert.

5.9.6 The suggested weld setup is as follows:

Welding current: $65 / 75$ amps DCSP 10-15 volts Arc length: $\quad 1 / 8$ inch Welding speed: $\quad$ 4-6 IPM (Manual)

5.9.7 This procedure requires tungsten inert gas (TIG) welding of filler passes. 
Im.20-S-0035

Section I

TABLE I

WEIDING SPECIFICATION FOR STAINLESS STEEL .100 INCH THICK AND THICKER USING THE GAS TUNGSTEN ARC PROCESS WITH "Y" RINGS

Applicable Materials (Not all inclusive):

Base Material

304 to 304

$304 \mathrm{I}$ to $304 \mathrm{I}$ or 304

316 to $316,304 \mathrm{~L}$ or 304

$316 \mathrm{I}$ to $316 \mathrm{I}, 316,304 \mathrm{I}$ or 304

321 to 321

347 to $347,316 \mathrm{I}, 316,304 \mathrm{I}$ or 304

General Parameters:

Thickness

Weld prep level angle

Weld prep land

Consumable Insert

Root Gap

Rod

Amperage

Voltage

Shield Gas

Purge Gas

Tungsten electrode $\underline{\text { Filler Material }}$

MIL-R-503I

308

308ELC

316

$316 \mathrm{ELC}$

349

349

$.100^{\prime \prime}$ and thicker

37-1/2 degrees, approx.

$1 / 32^{\prime \prime} \max$.

"Y" Ring

None

$3 / 32^{\prime \prime}, 1 / 8$ filler metal

Root pass 65/75

Filler passes $65 / 175$

$12 / 18$

16/22 CFH Argon

5/20 CFH Argon

$3 / 32$, round $2 \%$ thoriated 
NTO-S-0035

SECTION II

5.6 Gas Tungsten Arc Built Welding of 300 Series Stainless Steel with a Root Gap.

5.6.1 Paragraphs 1.0 through 5.0 are an integral part of this procedure.

5.6.2 Consumable Inserts, backing rings, or similar items will not be used.

5.6.3 Intexpass temperature must not exceed $360^{\circ} \mathrm{F}$. 
NTO-S-0035

Section II

TABLE I

WEIDING SPECIFICATION FOR STAINLESS STEEL .100 INCH THICK AND THICKER USING THE GAS TUNGSTEN ARC PROCESS

Applicable Materials (Not all inclusive):

Base Material

304 to 304

$304 \mathrm{~L}$ to $304 \mathrm{~L}$ or 304

316 to $316,304 \mathrm{I}$ or 304

$316 \mathrm{I}$ to $316 \mathrm{I}, 316,304 \mathrm{I}$ or 304

321 to 321

347 to $347,316 \mathrm{~L}, 316,304 \mathrm{~L}$ or 304

\section{Filler Material}

MII-R-5031

308

308ELC

316

$316 \mathrm{ELC}$

349

349

General Parameters:

Thickness

$.100 "$ and over

Weld prep., land

$1 / 16^{\prime \prime} \pm 1 / 32^{\prime \prime}$

Root gap

$1 / 16^{\prime \prime} \pm 1 / 32^{\prime \prime}$

Rod

1/16", 3/32", 1/8" type

same as filler metal

Amperage

Root pas - 65/85

Filler passes - 65/175

Voltage

$12 / 18$

Shield gas

16/22 CFH Argon

Purge Gas

5/20 CFH Argon

Tungsten electrode

$3 / 32 "$, round; $2 \%$ thoriated 
NTO-S-0035

\section{SECTION III}

5.6 Manual Shielded Metal Arc Butt Welding of 300-Series Stainless Steel.

5.6.1 Paragraphs 1.0 through 5.5 are an integral part of this procedure.

5.6.2 Consumable inserts, backing rings or similar items will not be used.

5.6.3 Interpass temperature must not exceed $350^{\circ} \mathrm{F}$.

5.6.4 The root pass on all piping shall be made using the Gas Tungsten Arc welding process. 
NTO-S-0035

Section III

TABIE I

WELDING SPECIFICATION FOR STAINLESS STEEL .100 INCH AND THICKER

USING THE GAS TUNGSTEN ARC PROCESS

Applicable Materials: (Not all inclusive)

Base Material

Filler Material

$\underline{\text { Root Passes }}$

MIL-R-5031

304 to 304

304 I to 304 I or 304

316 to $316,304 \mathrm{~L}$ or 304

347 to $347,316 \mathrm{~L}, 316,304 \mathrm{~L}$ or 304349
308

308ELC

316
Filler Passes

MIL-E $-22200 / 2$

308

$308 \mathrm{I}$

316

349

\section{General Parameters}

Thickness

Weld prep bevel angle

Weld prep land

Root gap

Rod

Amperage $.100^{\prime \prime}$ and over

37-1/2 degrees, approx.

1/32" min., 3/64" max.

$1 / 16^{\prime \prime} \pm 1 / 32^{\prime \prime}$

$1 / 8^{\prime \prime}, 5 / 32^{\prime \prime}, 3 / 16^{\prime \prime}$

Root pass - 80 - 105

3/16" - 125-175

$5 / 32^{\prime \prime}-100-140$

$12 / 18$

Voltage

used. The base metal shall be on

D.C. Reverse polarity current
the negative side of the line.

Shield gas

Purge gas

Tungsten electrode
16/22 CFH Argon

5/20 CFH Argon

$3 / 32 "$, round $2 \%$ thoriated 
NTO-S-0035

SECTION IV

5.6 Gas Tungsten Arc Welding in conjunction with "Y" Type consumable inserts using Carbon steel.

5.6.1 Paragraphs 1.0 through 5.5 are an integral part of this procedure.

5.6.2 The " " Ring Insert shall be made of a material compatible with both the base material and the filler material. 5.6.2.1 The "Y" Ring Insert shall be cleaned of all oxides by methods described in section 5.2.2, prior to tack welding:

5.7 TACK WEIDING OF "Y" RING INSERT

5.7.1 Tack welding of the " $Y$ " Ring Insert is not required if the insert is a pre-formed solid ring and the joint can be clamped in position.

5.7.2 Where tack welds are used, the fusion of the insert arm to the bevel is sufficient. A tack weld spacing of $2-4$ inches is adequate. All tack welds shall be made on the outside of the part.

5.7.3 Locate the "Y" ring on one side of joint as shown in Figure 3. Then tack weld as per 5.7.2. Rings over $1 / 2^{\prime \prime}$ in diameter are rolled with an overlap. Tack to first assembly section to within a few inches of overlap then secure the overlap with a vice-grip pliers and saw completely through the side-by-side insert sections. This will leave a gap the width of the saw blade which 
NTO-S-0035

Section [V

is to be bridged with weld rod after the interior purge is complete and prior to starting the weld. Locate the second half of the assembly in its proper position, and tack weld using a slight offset sequence from the first set of tacks.

\subsection{ALIGNMENT}

5.8.1 The outward inclined arms of the "Y" R.ing Insert creates a double-cup effect with the assembly becoming self-aligning.

5.8.2 In cases where there is local misalignment between the two pipes which are to be welded, the insert arm may be pushed into position.

5.8.3 Where large misalignment gaps exist, it is necessary that filler metal be added simultaneously with reduction of the insert. The filler rod is held in contact with the inset vee of the " $Y$ " Ring Insert and allowed to enter the weld puddle without rod movement as the arc advances.

\subsection{ROOT WEIDS}

5.9.1 Interpass temperature must not exceed $350^{\circ} \mathrm{F}$.

5.9.2 Prior to starting the root pass, a 1/2" long weld should be started $180^{\circ}$ from the point the weld bead is to be started. If the weld is not to be started immediately, a second $1 / 2$ " long weld should be made at the starting point ( $180^{\circ}$ from the first $1 / 2^{\prime \prime}$ long weld).

5.9.3 Vertical welds (pipe in the horizontal plane) shall be started at the bottom of the pipe and proceed towards the top. 
NTO-S-0035

Section IV

5.9.4 Advancement of the torch is determined by breakdown of the Vee formed by inclined arms of the insert. As the arms are melted and drawn into the crater, there is a "wetting action" up the beveled sides. The molten weld surface becomes slightly concave as the root-pass fusion is established.

5.9.5 Torch movement should be in a forward direction of travel. Side movement or weaving shall not exceed the width of the "Y" Ring Insert.

5.9.6 The suggested weld setup is as follows:

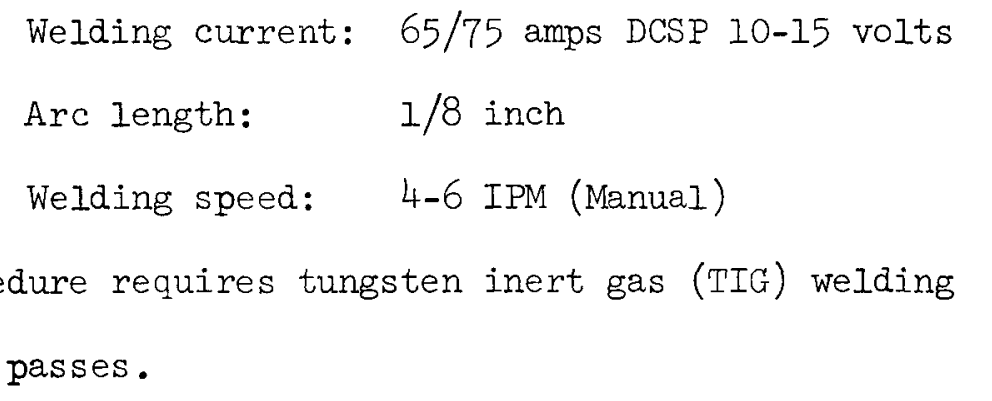


NTO-S-0035

Section IV

TABIE I

HEAT TREATMENT

Stress relief requirements shall be in accordance with ASME, Sec. VIII, Subsection C, Part USC56.

WELDING SPECIFICATION FOR CARBON STEEL WITH .100 INCH THICK AND HFAVIER, USING THE GAS TUNGSTEN ARC PROCESS WITH CONSUMABLE INSERT

Applicable Materials

Base Material

Filler Material

SA-53 SA-192

MIL-R-5632

SA-83 SA-210

E7018

SA-106 SA-214

SA-135 SA-226

SA-178 SA-333

SA-179 SA-334

General Parameters

Thickness

$.100 "$ and over

Weld prep bevel angle

37-1/2 degrees, approx.

Weld prep land

$1 / 23^{\prime \prime} \min ., 1 / 32^{\prime \prime}$

Consumable inert

1/8", 5/32", type 131

Root gap

None

Rod

$3 / 32^{\prime \prime}, 1 / 8^{\prime \prime}$ type same as filler metal

Amperage

Root pass - 65/85

Filler passes - 65/175

Voltage

$12 / 18$

Shield gas

16/22 CFH Argon

Purge gas

$5 / 20 \mathrm{CFH}$ Argon

Tungsten electrode

$3 / 32 "$, round, $2 \%$ thoriated

NOTE: Carbon steel inserts and TIG wire have an oil base coating to prevent rust - this coating must be completely removed by use of degreasing solvent prior to welding. 
5.6 Gas Tungsten Arc Welding on Steels "Other Than" Stainless Steel with a Root Gap.

5.6.1 Paragraphs 1.0 through 5.5 are an integral part of this procedure.

5.6.2 Consumable inserts, backing rings, or similar items will not be used.

5.6.3 Interpass temperature must not exceed $360^{\circ} \mathrm{F}$.

5.6.4 Small stringer beads using low heat input will be used.

5.6.5 The welding speeds will be kept low to minimize porosity. 
NTO-S-0035

Section V

TABLE I

\section{HEAT TREATMENT}

Stress relief requirements shall be in accordance with ASME, Sec. VIII,

Subsection C, Part USC 56.

WEIDING SPECIFICATION FOR CARBON STEEL WITH .100 INCH THICKIESS AND

OVER, USING THE GAS TUNGSTEN ARC PROCESS

Applicable Materials

Base Material

SA-53 SA-193

SA-83 SA-210

SA-106 SA-214

SA-135 SA-226

$\mathrm{SA}-178 \quad \mathrm{SA}-333$

SA-179 SA-334
Filler Material

MIL-R- 5632

$\mathrm{E}-7018$

General Parameters

Thickness

$.100^{\prime \prime}$ and over

Weld prep bevel angle

37-1/2 degrees, approx.

Weld prep land

$1 / 32^{\prime \prime} \min$., 3/64" $\max$.

Root gap

$1 / 16^{\prime \prime}, 1 / 8^{\prime \prime}$

Rod

1/16", 3/32", I/8" type same as filler metal

Amperage

Root pass - 65/85

Filler passes - 65/175

Voltage

$12 / 18$

Shield gas

16/22 CFH Argon

Purge gas

5/20 CFH Argon

Tungsten electrode

$3 / 32 "$, round, $2 \%$ thoriated

NOTE: Carbon steel wire has an oil-base coating to prevent rust - this coating must be completely removed prior to welding by wiping with a degreasing solvent. 
NTO-S-0035

SECTION VI

5.6 Manual Shielded Metal Arc Butt Welding of Steels "Other Than" Stainless Steel with a Root Gap.

5.6.1 Paragraphs 1.0 through 5.5 are an integral part of this procedure.

5.6.2 Consumable inserts, backing rings, or similar items will not be used.

5.6.3 Interpass temperature must not exceed $350^{\circ} \mathrm{F}$.

5.6.4 The root pass on all piping shall be made using the Gas Tungsten Arc welding process. 
NTO-S-0035

Section VI

TABLE I

HEAT TREATMENT

Stress relief requirements shall be in accordance with ASME Sec. VIII, Subsection C, Part UCS-56.

WELDING SPECIFICATION FOR CARBON STEEL . 100 INCH AND THICKER

USING THE MANUAL SHIELDED METAL ARC PROCESS

Applicable Materials

Base Material

Filler Material

MIL-E-22200/I

SA-53 SA -192

$\mathrm{E}-7018$

SA-83 SA-210

SA-106 SA-214

SA-135 SA-226

SA-178 SA-333

SA-179 SA-334

\section{General Parameters}

Thickness

Weld prep bevel angle

$.100 "$ and thickness

Weld prep land

37-1/2 degrees, approx.

Root gap

$1 / 32^{\prime \prime} \min ., 3 / 64^{\prime \prime} \max$.

Rod size

$1 / 16 \pm 1 / 32 "$

Amperage

$1 / 8^{\prime \prime}, 5 / 32^{\prime \prime}, 3 / 16^{\prime \prime}$

$1 / 8^{\prime \prime}, 70-130$

$5 / 32^{\prime \prime}, 110-165$

$3 / 16^{\prime \prime}, 140-225$

Voltage

$12-40$

D. C. Reverse polarity current shall be used. The base metal shall be on the negative side of the line.

Amperage

Voltage

Shield Gas

Purge Gas

Tungsten Electrode
Root Pass - 65/85

$12 / 18$

16/22 CFH Argon

5/20 CFH Argon

3/32", Round, $2 \%$ Thoriated 
NTO-S-0035

SECTION VII

5.6 Gas Tungsten Arc Welding on Aluminum.

5.6.1 Paragraphs 1.0 through 5.5 are an integral part of this procedure.

5.6.2 Interpass temperature must not exceed $300^{\circ} \mathrm{F}$.

5.7 BASE METAL

5.7.1 The base metal will conform to the applicable requirements of $P$ number groups $21,22,23$, and 24 . See Table 1 of this Section.

5.8 FILLER METAL

5.8.1 The filler metal will be annealed bare wire conforming to one of the $F$ numbers 21 through 23 as specified in Table 1 of this section.

NOTE: Filler metal having no $F$ number will be qualified as a separate procedure. Filler material shall comply with MIL-E-16053.

\subsection{SHIELDING MEDIA}

5.9.1 Argon, helium or a mixture of argon and helium gas will be used as a shield.

5.10 The number of passes, electrode diameter and filler metal fur each pass, and mean amperage values for each pass are specified in Figure 4 and 5 for each joint thickness.

5.10.1 Apply weld metal to avoid undercutting the weld groove or the adjoining material. Deposit a weld reinforcement of $1 / 16$ to $1 / 8$ inch with a smooth gradual increase in thickness from the edge to the center of the weld. 
NTO-S-0035

Section VII

5.10.2 When the parent material thickness is $1 / 4$ inch or over, a preheat of $150^{\circ} \mathrm{F}$, maximum, shall be used. 
NTO-S-0035

Section VII

TABLE I

FILLER MATERIAL FOR VARIOUS ALUMINUM ALLOYS

\begin{tabular}{|c|c|c|c|}
\hline Base Material & P N Iumber & Filler Alloy & F Number \\
\hline 1100 & 21 & 1100 & 21 \\
\hline 1100 & 21 & 4043 & 23 \\
\hline 3003 & 21 & 1.100 & 21 \\
\hline 3003 & 21 & 4043 & 23 \\
\hline 3003 & 21 & 5183 & 22 \\
\hline 5050 & 21 & 1100 & 21 \\
\hline 5050 & 21 & 4043 & 23 \\
\hline 5050 & 21 & 5154 & 22 \\
\hline 5050 & 21 & 5183 & 22 \\
\hline 5050 & 21 & 5356 & 22 \\
\hline 5052 & 22 & 5154 & 22 \\
\hline 5052 & 22 & 5183 & 22 \\
\hline 5154 & 22 & 4043 & 23 \\
\hline 5154 & 22 & 5154 & 22 \\
\hline 5154 & 22 & 5183 & 22 \\
\hline 5154 & 22 & 5356 & 22 \\
\hline 5083 & 24 & 1100 & 21 \\
\hline 5083 & 24 & 5154 & 22 \\
\hline 5083 & 24 & 5183 & 22 \\
\hline 5083 & 24 & 5356 & 22 \\
\hline 5086 & 22 & 5.154 & 22 \\
\hline 5086 & 22 & 5183 & 22 \\
\hline 5086 & 22 & 5356 & 22 \\
\hline 6061 & 23 & 1100 & 21 \\
\hline 6061 & 23 & 4043 & 23 \\
\hline 6061 & 23 & 5154 & 22 \\
\hline 6061 & 23 & 5356 & 22 \\
\hline 6061 & 23 & 5556 & 22 \\
\hline \multicolumn{4}{|c|}{ VII-3 } \\
\hline
\end{tabular}


NTO-S-0035

SECTION VIII

5.6 Gas Metal Arc Welding on Aluminum

5.6.1 Paragraphs 1.0 through 5.5 are an integral part of this procedure.

5.6.2 Base Metal

5.6.2.1 The base metal will conform to the applicable requirements of $\mathrm{P}$ number groups $21,22,23$ and 24, as shown in Table I of this section.

5.7 FILIER METAL

5.7.1 The filler metal will be annealed bare wire conforming to one of the $F$ numbers 21 through 23 .

5.7.1.1 Filler metal having no $F$ number will be qualified as a separate procedure.

5.7.1.2 Filler material shall comply with MII-E-16053.

5.8 SHIEIDING MEDIA

5.8.1 Argon gas will be used as a shield. An inert atmosphere (outside the shield) is not necessary. A mixture of helium and argon may be used providing the helium does not exceed $75 \%$ of the mixture.

5.9 WELDING

5.9.1 Preheat

5.9.1.1 When the parent material thickness is $1 / 4$ inch or greater, a preheat of $150^{\circ} \mathrm{F}$, maximum shall be used The welding machine, complete with the welding torch and accessories, shall be checked at the following times to insure equipment is functioning properly:

VIII-I 
NTO-S-0035

Section VIII

(a) At the start of each working shift.

(b) Whenever a maintenance change in equipment or accessories is required.

(c) Whenever the wire spool is changed.

5.9.1.2 The weld equipment check shall consist of welding and testing a sample joint as described in Figure 6. In order to be considered acceptable, the weld shall have a uniform and clean surface appearance; and the fractured face (except for $1 / 2$ inch at each end) shall have no unfused areas, entrapped oxides or excessive porosity.

5.9.1.3 Direct current, reverse polarity, shall be used. Recommended amperage and voltage for various base metal thicknesses are listed in Table II.

5.9.1.4 High purity welding grade Argon shall be used. Smooth wire drive rolls are required for aluminum wire. The flexible conduit supporting the wire between the drive rolls and the torch shall be equipped with a nylon insert liner to provide smooth wire feeding. Periodic replacement of the liner, as wear takes place, is required. 
NTO-S-0035

jection VIII

5.9.1.5 String beads or slightly weaving beads are

preferred, with the maximum width of the weld

deposit to be approximately ten times the

diameter of the welding wire being used.

5.9.1.6 In multipass welds, each pass must be wire brushed, using a stainless steel brush in accordance with Section 5.2

5.9.1.7 Weld pass starts and finish craters shall be examined with a $10 \mathrm{X}$ glass and blended to remove all defects. Interpass temperature must not exceed $300^{\circ} \mathrm{F}$. 


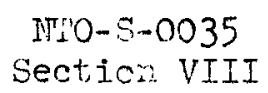

TABLE I

FILIER MATERIAL FOR VARIOUS ALUMINUM ALIOYS

\begin{tabular}{|c|c|c|c|}
\hline Base Material & $P$ Number & Filler Alloy & F Number \\
\hline 1100 & 21 & 1100 & 21 \\
\hline 1100 & 21 & 4043 & 23 \\
\hline 3003 & 21 & 1100 & 21 \\
\hline 3003 & 21 & 4043 & 23 \\
\hline 3003 & 21 & 5183 & 22 \\
\hline 5050 & 21 & 1100 & 21 \\
\hline 5050 & 21 & 4043 & 23 \\
\hline 5050 & 21 & 5154 & 22 \\
\hline 5050 & 21 & 5183 & 22 \\
\hline 5050 & 21 & 5356 & 22 \\
\hline 5052 & 22 & 5154 & 22 \\
\hline 5052 & 22 & 5183 & 22 \\
\hline 5052 & 22 & 5356 & 22 \\
\hline 5154 & 22 & 4043 & 23 \\
\hline 5154 & 22 & 5154 & 22 \\
\hline 5154 & 22 & 5183 & 22 \\
\hline 5154 & 22 & 5356 & 22 \\
\hline 5083 & 24 & 1100 & 21 \\
\hline 5083 & 24 & 5154 & 22 \\
\hline 5083 & 24 & 5183 & 22 \\
\hline 5083 & 24 & 5356 & 22 \\
\hline 5086 & 22 & 5154 & 22 \\
\hline 5086 & 22 & 5183 & 22 \\
\hline 5086 & 22 & 5356 & 22 \\
\hline 6061 & 23 & 1100 & 21 \\
\hline 6061 & 23 & 4043 & 23 \\
\hline 6061 & 23 & 5154 & 22 \\
\hline 6061 & 23 & 5356 & 22 \\
\hline 6061 & 23 & 5556 & 22 \\
\hline
\end{tabular}


NTO - S-0035

Section VIII

TABLE II

\begin{tabular}{l|c|c|c|c|c}
\hline \multirow{2}{*}{$\begin{array}{c}\text { Plate } \\
\text { Thickness }\end{array}$} & \multicolumn{2}{|c|}{ Welding Voltage } & Welding Amperage & $\begin{array}{c}\text { Argon Flow } \\
\text { Cubic Ft/H }\end{array}$ \\
\cline { 2 - 6 } & $3 / 64^{\prime \prime}$ Wire & $1 / 16^{\prime \prime}$ Wire & $3 / 64^{\prime \prime}$ Wire & $1 / 16^{\prime \prime}$ Wire & $35-40$ \\
$3 / 8$ & $20-22$ & $22-24$ & $120-140$ & $170-190$ & $30-50$ \\
$1 / 2$ & $22-24$ & $24-26$ & $140-170$ & $190-220$ & $40-50$ \\
$5 / 8$ & $24-26$ & $25-27$ & $170-210$ & $220-260$ & $50-55$ \\
$3 / 4 \&$ & $25-27$ & $26-28$ & $170-210$ & $220-260$ & $50-55$ \\
Over & $25-27$ & $27-30$ & $170-210$ & $220-260$ & $55-60$ \\
\hline
\end{tabular}


$\mathrm{IrT}_{\mathrm{O}}-\mathrm{3}-0035$

SECTIOj: $\perp X$

5.6 Gas Tungsten Arc Butt W lding of Invar with a Root Gap

5.6.1 Paragraphs 1.0 through 5.5 are an integral part of this procedure.

5.6.2 Consumable Inserts, backing rings or similar items will not be used.

5.6.3 Interpass temperature must not exceed $360^{\circ} \mathrm{F}$.

5.6.4 SmalI stringer beads using low heat input will be ised.

5.6.5 The welding speeds will be kept low to minimize porosity. 


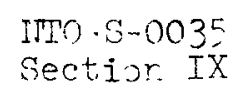

TABLE I

WELDING SPECIFICATION FOR INVAR . 100 INCH THICK AND HEAVIER

USING THE GAS TUNGSTEN ARC PROCESS

\section{Applicable Materials}

Base Material

Iron - 36 percent nickel

a. Chemical Composition of

Filler Wire

Element
$\mathrm{Ni}$
$\mathrm{Si}$
$\mathrm{Mn}$
$\mathrm{Al}$
$\mathrm{Ti}$
$\mathrm{P}$
$\mathrm{Pb}$
$\mathrm{S}$
$\mathrm{O}$
$\mathrm{Ca}$
$\mathrm{Fe}$

$\mathrm{Fe}$

$\begin{array}{ll}\frac{\text { Aim }}{36.00} & \frac{\text { Range } \%}{34 \text { to } 38} \\ 0.10 & 0.08 \text { to } 0.15 \\ 0.25 & 0.25 \mathrm{Max} . \\ 3.00 & 2.2 \text { to } 3.5 \\ 0.07 & 0.07 \text { added } \\ 1.00 & 0.05 \text { to } 1.5 \\ \text { Low } & 0.01 \\ \text { Low } & 0.01 \\ \text { Low } & 0.02 \\ \text { Low } & 0.010 \text { Max. } \\ 0.05 & 0.05 \text { added } \\ \text { Bal. } & \text { Bal. }\end{array}$

General Parameters
Filler Material

Modified Invar Wire

Bal.

\begin{tabular}{ll}
\multicolumn{2}{c}{ General Parameters } \\
Thickness & $.100^{\prime \prime}$ and over \\
Weld prep., land & $1 / 32^{\prime \prime} \mathrm{min} ., 3 / 32^{\prime \prime} \max$. \\
Root gap & $1 / 16^{\prime \prime} \pm 1 / 32^{\prime \prime}$ \\
Rod & $1 / 16^{\prime \prime}, 3 / 32^{\prime \prime}, 1 / 8^{\prime \prime}$ type \\
& same as filler metal \\
Amperage & Root pass $-35 / 40$ \\
& Filler passes $-70 / 90$ \\
Voltage & $12 / 18$ \\
Shield Gas & $16 / 22 \mathrm{CFH}$ Argon \\
Purge gas & $5 / 20 \mathrm{CFH}$ Argon \\
Tungsten electrode & $3 / 32^{\prime \prime}$, round $2 \%$ thoriated
\end{tabular}


iTi $-3-0035$

SECTION X

5.6 Gas tungsten Arc Butt Welding of Invar to Stainless Steel with

a Root Gap.

5.6.1 Paragraphs 1.0 through 5.5 are an integral part of this procedure.

5.6.2 Consumable inserts, backing rings, or similar items

will not be used.

5.6.3 Interpass temperature must not exceed $360^{\circ} \mathrm{F}$.

5.6.4 Small stringer beads using low heat input will be used.

5.6.5 The welding speeds will be kept low to minimize porosity. 


\section{No-s-0035}

Section $X$

TABLE I

WELDING SPECIFICATION FOR INVAR TO STAINIESS STEEL . 100 INCH THICK AND HEAVIER USING THE GAS TUNGSTEN ARC PROCESS

Applicable Materials

Base Material

Iron - 36 percent nickel

a. Chemical composition of Filler Wire

\section{Element}

$\mathrm{Ni}$

$\mathrm{C}$

Si

$\mathrm{Mn}$

AI

Ti

$P$

$\mathrm{Pb}$

$\mathrm{S}$

0

$\mathrm{Ca}$

Fe
Aim

36.00

0.10

0.25

3.00

0.07

1.00

Low

Low

Low

Low

0.05

Bal.
Filler Material

Modified Invar Wire

Range \%

34 to 38

0.08 to 0.15

$0.25 \operatorname{Max}$.

2.2 to 3.5

0.07 added

0.5 to 1.5

0.01

0.01

0.02

0.010 Max.

0.05 added

Bal.

\section{General Parameters}

Thickness

Weld prep., land

Root gap

Rod

Amperage

Voltage

Shield gas

Purge gas

Tungsten electrode $.100^{\prime \prime}$ and over

$1 / 32^{\prime \prime} \min$, 3/32" $\max$.

$1 / 16^{\prime \prime} \pm 1 / 32^{\prime \prime}$

1/16", 3/32", 1/8" type same as filler metal

Root pass - 35/40

Filler pass - 70/130

$12-18$

16-22 CFH Argon

5-20 CFH Argon

$3 / 32 "$, round $2 \%$ thoriated 


\section{NTO-S-0035}

\section{SECTION XI}

5.6 Gas Tungsten Arc Butt Welding of Carbon Steel to Stainless Steel with a Root Gap.

5.6.1 Paragraphs 1.0 through 5.5 are an integral part of this procedure.

5.6.2 Consumable inserts, backing rings, or similar items will not be used.

5.6.3 Interpass temperature must not exceed $360^{\circ} \mathrm{F}$.

5.6.4 Attach all purge connections and purge the internal area with $20 \mathrm{CFH}$ Argon for a minimum of 5 minutes.

NOTE: In all tacking, $10 \mathrm{CFH}$ Argon will be used as a backup.

5.6.5 Small stringer beads using low heat input will be used. 5.6.6 The welding speeds will be kept low to minimize porosity. 
NTO-S-0035

Section XI

TABLE I

HEAT TREATMENT

Stress relief requirements shall be in accordance with ASME Sec. VIII Subsection C, Part UCS 56.

WEIDING SPECIFICATION FOR CARBON STEEL TO STAINLESS STEEL . 100 INCH AND THICKER USING THE GAS TUNGSTEN ARC PROCESS

Applicable Materials

Base Material

Carbon Steel Stainless Steel

SA -53

$\mathrm{SA}-83$

$\mathrm{SA}-106$

SA-135

$\mathrm{SA}-178$

SA-179

SA-192

$S A-210$

SA-21 4

SA-226

SA-333

$\mathrm{SA}-334$

SA-105

SA-181

SA-216

SA-352
304

$304 \mathrm{~L}$

316

$316 \mathrm{I}$

347
Filler Material

Mil-R-5031

310 
$\ln 0-5-0035$

section $x^{T}$

TABIE II

\section{General Parameters}

$\begin{array}{ll}\text { Thickness } & .100^{\prime \prime} \text { wall and over } \\ \text { Weld Prep Bevel Angle } & 37-1 / 2 \text { degrees approx. } \\ \text { Weld Prep Land } & 1 / 32^{\prime \prime} \text { min., } 3 / 64^{\prime \prime} \text { max. } \\ \text { Root Gap } & 1 / 16^{\prime \prime}, 1 / 8^{\prime \prime} \\ \text { Rod } & 1 / 16^{\prime \prime}, 3 / 32^{\prime \prime}, 1 / 8 " \text { type same } \\ & \text { as filler metal } \\ \text { Amperage } & \text { Root pass }-65 / 85 \\ & \text { Filler pass }-65 / 175 \\ \text { Voltage } & 12-18 \\ \text { Shield gas } & 16-22 \mathrm{CFH} \text { Argon } \\ \text { Purge gas } & 5-20 \mathrm{CFH} \text { Argon } \\ \text { Tungsten Electrode } & 3 / 32^{\prime \prime}, \text { round, } 2 \% \text { thoriated }\end{array}$

ALTERNATE METHOD FOR WELDING CARBON STEEL TO STAINLESS STEEL . 100 INCH

AND THICKER USING THE GAS TUNGSTEN ARC PROCESS

It is permissible to use the technique of "buttering" the carbon steel joint face with the $\mathrm{E} 310$ weld wire and then using the appropriate stainless steel wəld wire as shown:

Applicable Materials

$\begin{array}{ll}\text { Stainless Steel } & \text { Filler Material } \\ 304 & \text { Mil-R-5031 } \\ 304 \mathrm{~L} & 308 \\ 316 & 308 \text { ELC } \\ 316 \mathrm{~L} & 316 \\ 347 & 316 \mathrm{ELC} \\ & 349\end{array}$


5.6 Manual Shieldad Metal Arc Butt Welding of Carbon Steel to Stainless Steel with a Root Gap.

5.6.1 Paragraphs 1.0 through 5.5 are an integral part of this procedire.

5.6.2 Consumable inserts, backing rings, or similar items will. not be used.

5.6.3 Interpass temperature must not exceed $360^{\circ} \mathrm{F}$.

5.6.4 Attach all purge connections and purge the internal area with $15 \mathrm{CFH}$ Argon for a minimum of 5 minulies. NOTE: In all tacking, $10 \mathrm{CFH}$ Argon will be used as a backup.

5.6.5 Small stringer beads using low heat input will be usea. 5.6.6 The welding speeds will be kept low to minimize porosisy. 
NTO-S-0035

Suction XII

TABIE I

HEAT 'DQSAIIVE'T!

Stress relief requirements shall be in accordance with AS'A Sec. VIII, Subsection C, Part UCi 5́́.

WEIDING SPECIFICATION FOR CARBON STEEL TO STAINIESS STEEL . 100 INCH AND THICKER USING THE MANUAL SHIELDED METAL ARC PROCESS

Applicable Materials

Base Material

$\begin{array}{lll}\text { Carbon Steel } & & \text { Stainless Steel } \\ \text { SA-53 } & 304 \\ \text { SA-83 } & & 304 \mathrm{~L} \\ \text { SA-106 } & & 316 \\ \text { SA-135 } & & 316 \mathrm{~L} \\ \text { SA-178 } & & 347 \\ \text { SA-179 } & \\ \text { SA-192 } & \\ \text { SA-210 } & \\ \text { SA-214 } & \\ \text { SA-226 } & \\ \text { SA-333 } & \\ \text { SA-334 } & \\ \text { SA-105 } & \\ \text { SA-181 } & \\ \text { SA-216 } & \\ \text { SA-352 } & \end{array}$

Filler Material

Mil-E-22200/2

310

310

310

310

310

310

310

310

310

310

310

310

310

310

310

310 
NTO-S-0035

Section XII

TABLE II

General Parameters

Thickness

.100 thickness and over

Weld Prep Fievel Angle

$37-1 / 2$ degrees - approx.

Weld Prep Land

$1 / 32^{\prime \prime} \min ., 3 / 4^{\prime \prime} \max$.

Root Gap

$1 / 16^{\prime \prime}-1 / 8^{\prime \prime}$

Rod Size

$1 / 8^{\prime \prime}, 5 / 32^{\prime \prime}, 3 / 16^{\prime \prime}$

Amperage

(1/8") 70-120

(5/32") 100-150

$\left(3 / 16^{\prime \prime}\right) 120-200$

Voltage

$12-35$

D. C. Reverse polarity current shall be used. The base metal shall be on the negative side of the line.

ALTERNATE METHOD FOR WELDING CARBON STEEL TO STAINLESS STEEL . 100 INCH

AND THICKER USING THE MANUAL SHIEIDED METAL ARC PROCESS

It is permissible to use the technique of "buttering" the carbon steel joint face with the E 310 weld wire and then using the

appropriate stainless steel weld wire as shown:

\section{Applicable Materials}

Stainless Steel

304

$304 \mathrm{~L}$

316

$316 \mathrm{~L}$

347
Filler Material

MiL-E-22200/2

308

308ELC

316

$316 \mathrm{ELC}$

347 